\title{
GENETICALLY MODIFIED FOOD SAFETY IN SUPPLY CHAIN
}

\author{
Dominik Kabus \\ Czestochowa University of Technology, Poland
}

\begin{abstract}
This paper addresses the problem of genetically modified food. In the first part of the article the author attempts to discuss European legislation regulating the issue of Genetically Modified Organisms (GMO). Next, there have been characterized the genetically modified raw materials of plant and animal origin. Particular attention was paid to management of genetically modified food safety in supply chain. In this context, the author describes the situation on the economic market. In the last part of the paper, the author reflects upon the safety and management strategies in the supply chain of genetically modified food.
\end{abstract}

Keywords: GMO, supply chain management, European legislation

DOI: $10.17512 /$ znpcz.2016.1.14

\section{Introduction}

The economic competition of countries, regions and particular producers, forces the biotechnologists to develop new solutions enhancing consumer quality of life. A hundred years ago creation of new species of living organisms was possible only by cross-breeding the existing species. This process, however, was especially laborious, long-lasting and didn't grant success. Presently it is achievable to improve quality and sensory characteristics of food by interfering in genetic code of plants and animals. Last few years have brought development in transgenic plants growing for commercial purposes, and the production volume is systematically growing worldwide.

Nowadays, the main assumption of genetic engineering is modification of plants of high economic importance. These changes are performed by introducing alien genes of plant or animal origin, conditioning emergence of new traits in plants, into natural genetic code of a crop. This way the resistance of plants to pests and herbicides increases. This way the GM plants become simpler and cheaper in cultivation, as compared to their previous forms. Often, modification concerns also the taste characteristics of edible plants or the intensity of colors of fruit and flowering plants. Genetic modification is also performed on animals, in order to improve the quality products created from animal-origin components. Because of the risk connected with genetic modification, or the moral, ethical and religious issues and doubts, it is necessary to properly mark and label the genetically modified products. Moreover, the aspect of storage and transportation of GMO is equally important. There is a risk of GMO products being in the same storage 
space as organic crops that are GMO-free. It is crucial to separate these kinds of crops, due to the consumers, who have the right to choose the kind of food they eat. It is especially important in case of GMO opponents. One of the main arguments against consumption of the GM products is that there is lack of reliable research on the influence of GM products consumption on living organisms in the long run, that is, a few decades' period of time. What is also called into question is the influence of GMO application on the previously unmodified natural ecosystem of living organisms. In order to ensure maximum safety in application of GMO, research is being conducted in many scientific centers in the world. Parallel, many countries decided to introduce legal restrictions concerning growing, transport, storage and processing of products containing GMO.

The aim of the study was to gain knowledge on consumer awareness and acceptance of food with GMO, in supply chain management.

\section{Transport and production legislation on GM products}

Genetic modifications have been practiced all over the world for many years. Despite that, modern day consumers are distrustful of the GMO food introduced on the market. In order to calm down the citizens and minimize the possible dangers coming from using GMO, the European Union (EU) proposed a series of directives and legislations to ensure better product management, that is, marking and better product detectability, as well as the GM product ingredients. From the moment of joining EU, Poland is obliged to follow all the norms and regulations of the European Community. The food that contains transgenic organisms, or consists of such organisms, is called GM food. The GMOs may be: animals, plants, bacteria which genetic composition has been modified (Sowa, Linkiewicz 2007, p. 66).

Many of today's food businesses consider production for innovation so that they reach market competitiveness (Jelonek 2014, s. 51-52).

The legal regulations on GMO, which are in force in Poland, have their roots in the international, European and Polish law. Among the international legislations, there are the Rio de Janeiro Convention on Biosafety and the Cartagena Protocol. In European law there are regulations that apply in each Member Country and directives implemented into national law (Sowa, Linkiewicz 2007, p. 45). The most important international agreement that regulates the issues of safe use of modern biotechnology achievements is the 1992 Rio de Janeiro Convention on Biodiversity (Wrześniewska-Wal I. 2008, s. 33-38). This agreement aims at protecting biological diversity by balanced use of the existing elements and just division of profits generated as a result of using genetic resources. This agreement ensures adequate access to genetic resources, transfer of technology and financing. The Convention determines that parties are obliged to manage GMO in an optimum way, by providing adequate means enabling recognition and control of dangers that have negative effect on the environment and may cause harm to human life. It also implies an obligation of cooperation, conducting scientific research and education of the society in the area of GM products. The convention determines the European Community as a Party. 
Another important element, regulating managements of GM products is the Cartagena Protocol on Biosafety (Council Decision 2002). On the $24^{\text {th }}$ of May, 2000, the Cartagena Protocol on Biosafety was also signed by Poland (total number of countries that signed the protocol: 102). The protocol details many important GMO definitions. It also contains records directly concerning living transgenic organisms meant for use as food, feed or a product intended for processing. The procedure of dealing with such organisms is determined in art. 11 of the protocol, connected with the Biosafety Clearing House (BCH) (Wrześniewska-Wal 2008, p. 33-38). This protocol states: "the Party that issues a final decision on national use, including introduction on the market of living modified organisms that may be subjected to transgenic mixing in order to be directly used as food, feed or for processing, is obliged to inform the Parties, through Biosafety Clearing House, about this decision within the period of fifteen days from the moment of issuing the decision." (Council Decision 2002)

The protocol clearly imposes the duty to inform about using GMO. The Quoted fragment reflects the willingness to ensure transparency of the flow of GMO. It also imposes duty to control this flow, and information transparency gives the possibility of social control over this phenomenon. "Lack of scientific certainty and knowledge on the scope of potential negative influence of living Modified Organism (MO) on the behavior and balanced use of biodiversity, of the import Party, also including dangers for human health, is not an obstacle in issuing a decision by that Party, on import of a given living MO. The import Party may, at any time, in the light of new scientific information on potential negative influence on behavior and balanced use of biodiversity, including dangers for human life, verify and change the decision on the intended transgenic movement (...)" (Council Decision 2002).

It follows from the above that the Cartagena Protocol refers directly to the concerns of GMO opponents. It seems that the decision-makers should tightly cooperate with the world of science in order to ensure maximum environmental and human health protection. However, particular attention is to be paid to the beginning of the quotation. The lack of data on the harmfulness of does not block issuing a decision on transgenic movement of living GMO. It may seem to be loose movement of living GMO. In my opinion, the rule governing here is not to block technological progress, as well as free and equal access to achievements within the scope of biotechnology. I believe that an equally important factor is the freedom of economic activity and potential possibility of blocking the development of some economic sector, while favoring other ones. Attention should also be paid to the possibility of changing decision that enables migration of GMO in any moment after recognizing possible danger to the environment and human health (Popa, Nowak, Nowakowska-Grunt, 2015, p. 2-3).

\section{Animals and genetically modified plants}

The modifications performed on animals and plants have aimed at creation of new breeds of animals and plant varieties. At first, the process of creation, and the mechanisms of transferring genetic information were an area outside of human 
interference. The modification was performed with the use of classic methods of selection, in favorable conditions for creating this variability. An important step was developing methods of DNA fragments manipulation. Presently, genetic modifications are performed in laboratory conditions ${ }^{1}$. The modifications of plants are currently a lot more popular than of animals, and the process of modification is longer, more complicated and costly (Brown, 2001, s. 87). The first plants to be genetically modified were tobacco and petunia. This took place in the 1980s.

The first product to be modified and introduced on market ${ }^{2}$ was the FlavrSavr long-life tomato. In Poland the first experiences with transgenic plants were gained in 1997 and concerned corn, beet, potatoes and rape. Currently research covers: corn, flax and potatoes. Plants of high economic value are modified more often than ornamental plants (Kawa 2015). The primary goals of plant modification are (Szajt, Włodarczyk 2012, s. 146-150):

- Creating resistance to herbicides, that is, chemical substances protecting plants. The modified plant produces enzymes that break down herbicides, becoming resistant to them. This way the following plants were modified: corn, soy, rape, tomatoes and tobacco.

- Creating resistance to diseases caused by bacteria, viruses, fungi. Resistance to root diseases was achieved by introducing transgene that codes enzymes: chitinase, glucanase, destroying their cell walls. Resistance to viral diseases was achieved by introducing into a plant, genes of a given virus as well as enzymes: replicase, protease (Anioł, Pruszyński, Twardowski, 2009, s. 9-10).

- Creating resistance to insects (vermins). Gene Bt responsible for this kind of resistance has been created from soil bacteria Bacillus thuringensis. It codes Cry protein, which is toxic only for particular species of insects, not for humans (Bartoszewski, Niemirowicz-Szczytt 1998, pp. 43-63).

- Creating resistance to environmental stress. The modified plants are resistant to frost, drought, high temperature, soil salinization, or environmental pollution. The modified plants are able to accumulate heavy metals and, while drawing them from soil, clean the environment (Bartoszewski 2007, s. 46-49.

- Improvement of qualitative and performance characteristics of the plants. It is, among others, modification causing delay in growing, due to which fruit and vegetables are fresh for longer.

GMO cultivation is constantly growing. At the end of 2015 acreage was around 90 million hectares in 21 countries $^{3}$. The latest report of International Service for the Acquisition of Agri-Biotech Applications (ISAAA) shows that the GMO cultivation numbers increased in 2011 by $8 \%$. Total area of GMO cultivation amounts to 160 million hectares. The United States is still a country of the largest

\footnotetext{
${ }^{1}$ Part of the organism's DNA is inserted into another organism's DNA. Then it is bred in a traditional way. Thanks to that there are created organisms of changed traits. Then, the bacteria, plants and animals that have been created in this way are called GMO or transgenic organisms.

${ }^{2}$ Modified tomatoes have been introduced on the market in the United States in 1994.

${ }^{3}$ The USA is a leader in transgenic plant growing. Soy, corn, cotton, rape and papaya are grown. Crops in USA constitute around $60 \%$ of the area of world's cultivation (Bartkowiak-Broda 2008, p. 22-28].
} 
area of these crops (69 million hectares), in Europe the area is estimated to be 110 thousand hectares ([http://www.forbes.pl/artykuly/sekcje/Wydarzenia/gmo-opanowuje -swiat-juz-160-mln-ha-upraw]). In 2014 the GMO crops were 181.5 million hectares and there is still a growing tendency.

Genetic modification of animals is a process much longer and more complicated than plant modification. Transgenic animals often catch diseases and are impotent. The animals are modified for scientific as well as practical purposes. Genetically modified animals serve as testers for new methods of curing various diseases, i.e. obesity or cancer. Practical application is focused on improvement of production qualities of transgenic animals, or obtaining desired traits such as faster growth. Modified animals are also used for production of substances applied in pharmaceutical industryvc (Wrześniewska-Wal 2008, s. 57-68).

\section{Safety of genetically modified food}

Management of large-scale production of plants began in highly developed countries. Each year the Member Countries of the EU import around 40 million tons of soy material. Supply chain of GM plants is controlled by numerous procedures ensuring consumer and product safety. The GM food cannot pose danger to human life and health. The factor of environmental and health safety determines the possibility of application of GMO for commercial purposes. Transgenic food admitted to trading is considered to be safe, just like GMO products in its composition. Still there are no results of numerous and long-term analyses of the influence of GM organisms on natural environment and human health (Anioł, Zimny 2008, s. 3-7).

Management of food safety is in other words a guarantee that the used product is not and will not be harmful for consumers' health (Brzozowska, Grabińska, Dacko, 2015, s. 24-30). In the estimation of safety there are taken into account, most importantly, toxic and allergenic properties of GMO. The best way of safety estimation of a new product is to compare it with a conventional product that is considered to be safe. The chemical composition and phenotypic characters are compared, evaluating component equivalence. If the new food is chemically and nutritionally equivalent to the already existing, it should be subject to the same procedures as the conventional one. The estimation of safety of GMO performed on the basis of comparison of GMO and conventional parental organism covers characteristics and comparative analysis in terms of nutritional values, antinutritional and allergenic toxic or endogenic components. It causes that it is possible to verify if within the process of genetic modification there were unwanted changes made.

Each genetically modified product requires permission and safety assessment made by the European Food Safety Authority (EFSA) under EU regulation no 1829/2003 for "genetically modified foods and feed." The permission may be granted only in case of genetically modified food and feed not having negative influence on human, animal health and the environment. This regulation sets forth the safety of GMO products in the whole food supply chain, ensuring consumer 
safety. The main element of food safety is the guarantee of identification of origin and product movement back and forth in the product supply chain, ensuring proper hygiene, quality and health level (Bezat-Jarzębowska, Jarzębowski 2013, s. 9-10).

Regulation number 1829/2003 requires placing suitable information of GM products. Consumers need to know that the purchased product is genetically modified. The label has to consist of: content, nutritional qualities, nutritional effects, application, influence on health of particular groups of people and animal species ${ }^{4}$. Each element along the supply chain should be clearly marked, in order to maintain proper flow of information. Monitoring of GMO according to the unified procedures along the whole supply chain creates the existence of proper information about applied technologies, quality and product hygiene for the potential consumer. It is also a warranty of healthy nature of the supplied food (Bezat-Jarzębowska, Jarzębowski 2013, s. 9-1).

Transport is an especially important issue in the GMO safety management (Mesjasz-Lech, Skowon-Grabowska 2014, s. 417-425). During transport of genetically modified organisms there apply several rules of the European law. The whole process of distribution is subject to a file of documents that have to be filled in, in order to concentrate the data on a given product. The conditions of transportation should be individually adjusted to the kind of the transported product. Generally, the GMO are transported in tightly closed containers ensuring optimum safety.

\section{Summary}

Marketing of genetically modified food and conducting research on it requires constructing relevant legal apparatus, which in Poland is manifested by the existence of EU directives, national and international legal acts. There exists a precisely defined procedure of introducing GM food onto Polish market. Identification of GMO and ensuring proper conditions in the whole supply chain are the guarantee of health, quality and proper product hygiene. GMO are subject to special legal regulations created for the consumer safety and protection.

\section{References}

1. Anioł A., Pruszyński S., Twardowski T., Zielona Biotechnologia - Korzyści i Obawy, Broszura: materiały edukacyjne, Polska Federacja Biotechnologii, Łódź 2009.

2. Bartoszewski G., Genetycznie modyfikowane organizmy - szanse i zagrożenia, [w:] Hewelke P. (red.), Zasoby przyrodnicze szansa zrównoważonego rozwoju: materiały szkoleniowe dla pracowników administracji samorzadowej, SGGW, Warszawa 2007.

3. Bartoszewski G., Niemirowicz - Szczytt K., Transformacja pomidora za pomoca Agrobacterium tumefaciens, „Biotechnologia” 1998.

\footnotetext{
${ }^{4}$ According to regulation no 1928/2003 each GM product, or created from modified raw materials should have notice on the label, saying "genetically modified" or "produced from genetically modified, i.e. corn. So, for example, refined edible oil from GM rape seeds requires marking. The present threshold is $0.9 \%$, below which marking is not required.
} 
4. Bezat-Jarzębowska A., Jarzębowski S, Znaczenie żywnościowych łańcuchów dostaw, [w:] Wieś Jutra 4(177), Warszawa 2013.

5. Brown A. T., Genomy, PWN, Warszawa 2001.

6. Brzozowska A., Grabińska A., Dacko M., Evolution of Supply Chain Management and Striving to Achieve Sustainable Development, [w:] Logistyka nr. 3, Poznań 2015, s. 24-30.

7. Decyzja Rady nr 2002/628 z dnia 25 czerwca 2002 r. dotyczaca zawarcia $w$ imieniu Wspólnoty Europejskiej Protokolu z Kartageny o bezpieczeństwie biologicznym do Konwencji o różnorodności biologicznej, Dz. Urz. WE L 628, z dnia 31.07.2002r.

8. http://www.forbes.pl/artykuly/sekcje/Wydarzenia/gmo-opanowuje-swiat-juz-160-mln-haupraw [dostep:10.12.2015].

9. Jelonek D. , Innowacje otwarte $w$ budowaniu konkurencyjnej przewagi przedsiębiorstwa, [w:] Innowacje i przedsiębiorczość. Teoria i praktyka, Dąbrowa Górnicza 2014, s. 51-52.

10. Kawa M., Rośliny transgeniczne GMO - przyktady modyfikacji, www.biotechnolog.pl/ gmo-4.htm, (dostęp: 10.04.2015).

11. Mesjasz-Lech A., Skowron-Grabowska Beata, Application of Information Technology in Supply Chain Management as Exemplified by Companies in Poland, [w:] Managing Organizations in Changing Environment. Models - Concepts - Mechanisms, Kraków 2014, s.417-425.

12. Popa D., Nowak C., Nowakowska- Grunt J., Regional Development Food Channels in Republic of Moldova, [w:] Logistyka nr 1, Poznań 2015, s.2-3.

13. Sowa S., Linkiewicz A., Rośliny genetycznie zmodyfikowane, [w:] Organizmy genetycznie zmodyfikowane, PZIiTS Oddziat Wielkopolski, Poznań 2007.

14. Szajt M., Włodarczyk A.(2012) Konsumencka ocena rynku bioproduktów w Polsce w świetle badań empirycznych, [w:] Roczniki Naukowe Stowarzyszenia Ekonomistów Rolnictwa i Agrobiznesu, T. 14, z.8 , s. 146-150.

15. Wrześniewska - Wal I., Żywność genetycznie zmodyfikowana aspekty prawne, UW, Warszawa 2008

\section{ZARZĄDZANIE BEZPIECZEŃSTWEM ŻYWNOŚCI GENETYCZNIE MODYFIKOWANEJ W ŁAŃCUCHU DOSTAW}

Streszczenie: Niniejsza praca podejmuje problem żywności genetycznie modyfikowanej. W pierwszej części artykułu podjęto próbę omówienia ustawodawstwa europejskiego regulującego kwestie GMO. Następnie scharakteryzowano surowce genetycznie zmodyfikowane pochodzenia roślinnego i zwierzęcego. Szczególną uwagę poświęcono zarządzaniu bezpieczeństwem żywności genetycznie zmodyfikowanej w łańcuchu dostaw.

Słowa kluczowe: GMO, zarządzanie łańcuchem dostaw, prawo europejskie 